Article

\title{
Wine Traceability Using Chemical Analysis, Isotopic Parameters, and Sensory Profiles
}

\author{
Federica Bonello (iD), Maria Carla Cravero* (i), Valentina Dell'Oro, Christos Tsolakis ${ }^{(D)}$ and \\ Aldo Ciambotti \\ CREA Research Centre for Viticulture and Enology, Via Micca 35, 14100 Asti, Italy; \\ federica.bonello@crea.gov.it (F.B.); valentina.delloro@crea.gov.it (V.D.); \\ christos.tsolakis@crea.gov.it (C.T.); aldo.ciambotti@crea.gov.it (A.C.) \\ * Correspondence: mariacarla.cravero@crea.gov.it; Tel.: +39-01-4143-3814
}

Received: 21 May 2018; Accepted: 23 July 2018; Published: 27 July 2018

\begin{abstract}
NMR/IRMS techniques are now widely used to assess the geographical origin of wines. The sensory profile of a wine is also an interesting method of characterizing its origin. This study aimed at elaborating chemical, isotopic, and sensory parameters by means of statistical analysis. The data were determined in some Italian white wines-Verdicchio and Fiano- and red wines-Refosco dal Peduncolo Rosso and Nero d'Avola-produced from grapes grown in two different regions with different soil and climatic conditions during the years 2009-2010. The grapes were cultivated in Veneto (northwest Italy) and Marches (central Italy). The results show that the multivariate statistical analysis PCA (Principal Component Analysis) of all the data can be a useful tool to characterize the vintage and identify the origin of wines produced from different varieties. Moreover, it could discriminate wines of the same variety produced in regions with different soil and climatic conditions.
\end{abstract}

Keywords: NMR; IRMS; sensory analyses; traceability; geographical origin; isotopes

\section{Introduction}

European consumers are increasingly aware of wine quality and safety. Thus, the traceability of wines is surely a key topic. Legally speaking, the determination of the geographical origin of a wine product is an aspect strictly related to its certification, especially for authentic wines. The Common Market Organisation (CMO), which is the E.U. regulation on the processing and marketing of wines, introduced in 2011 two appellations aimed at harmonizing and integrating national laws and protocols: PDO (Protected Designation of Origin) and PGI (Protected Geographical Indications). In Italy, the production and commercialization of these wines represent an important sector of the country's economy. The new appellations, named DOP and IGP in Italian language, integrate the existing DOC, DOCG, and IGT. Moreover, autochthonous varieties have had a remarkable development in recent years. It follows that the enhancement of the methods used to verify the geographical origin of authentic wines is very important for their commercial success. Laboratories that provide controls have to develop more advanced methods of analysis able to find out frauds or to detect any contaminants present even in trace amounts [1]. Recently, some authors [2,3] proposed $\delta^{15} \mathrm{~N}$ as a further isotopic marker for the geographical characterization of grape products.

The strontium isotopic ratio $87 \mathrm{Sr} / 86 \mathrm{Sr}$ can also be used for the traceability and authentication of wine [4]. In 2017, Moreira [5] showed that nanofiltration (NF), a membrane process with several applications in oenology, does not influence this isotopic ratio.

Isotopic techniques SNIF-NMR (Site Specific Natural Isotope Fractionation, Nuclear Magnetic Resonance) and IRMS (Isotopic Ratio Mass Spectroscopy) are now widely used to verify the origin of food and beverages. SNIF-NMR, a specialization of magnetic resonance, was developed in France 
by Gérard Martin [6] and his team in the late 1980s and was soon applied in the detection of wine frauds or nonconformities to law such as watering, sugaring, or the addition of exogenous sugars [7]. Subsequently, these methods were also used in the determination of the geographical origin of wines. To this aim, the variation of the following isotopic parameters are evaluated: isotopic data obtained by NMR techniques-parameter (D/H)I ppm—combined with those for IRMS—relations $\delta^{13} \mathrm{C} \% \mathrm{vs}$. PDB $\delta^{18} \mathrm{O} \%$ vs. SMOW and sensory analyses. In addition, isotopic ratios should be compared to reference databases.

The effectiveness of stable isotopes ratios $(\mathrm{D} / \mathrm{H}) \mathrm{I},{ }^{13} \mathrm{C} /{ }^{12} \mathrm{C}$, and ${ }^{18} \mathrm{O} /{ }^{16} \mathrm{O}$ in the assessment of the geographical origin of wines is affected by the natural variability of these parameters. Thus, their efficiency in the identification of wines improves if they are used jointly. (D/H)I and ${ }^{18} \mathrm{O} /{ }^{16} \mathrm{O}$ ratios depend on latitude but, in the meantime, ${ }^{18} \mathrm{O} /{ }^{16} \mathrm{O}$ is noticeably modified by the meteorological conditions during grape ripening. The most powerful ratios used to discriminate the areas of origin are $(\mathrm{D} / \mathrm{H}) \mathrm{I}$ and ${ }^{18} \mathrm{O} /{ }^{16} \mathrm{O}[7,8]$.

There is a wide range of literature on this subject. The most recent works [9-11] take into account the use of NMR-IRMS in the evaluation of climatic and geographical origin.

In addition, it is possible to integrate isotopic data with those obtained by sensory analyses. This can help to assess wine origin or distinguish wines from different areas. Only a few studies examine the possible relation between sensory data and isotope data. Rochfort et al. [12] showed that some mouth-feel parameters identified from sensory analysis can be usefully correlated to NMR-based metabolomics analysis of wine.

As part of a project on the geographical and varietal traceability of wines (QUALITEC-CRA), the relation among stable isotopes was evaluated in order to differentiate the areas of productions in northern and central Italy.

Thus, this work aimed at characterizing wines obtained by two white grape varieties, Fiano and Verdicchio, and two red grape varieties, Nero d'Avola and Refosco dal Peduncolo Rosso, cultivated in two regions, Veneto and Marches, located respectively in north and central Italy, during two vintages (2009-2010). Isotopic analyses (NMR and IRMS) and chemical and sensory analyses were determined to verify if together they could differentiate the wines of the same variety produced with grapes from the two production areas.

\section{Materials and Method}

The samples of Fiano and Verdicchio (white varieties) and Refosco dal Peduncolo Rosso and Nero d'Avola (red varieties) came from Veneto and Marches (vintages 2009 and 2010).

The vineyards had different soil characteristics. Veneto vineyards were situated in the volcanic area of Lessini Mountains (province of Vicenza) in Mason for Refosco dal Peduncolo Rosso and in Gambellara for Verdicchio; the Fiano vineyard was located in Piavon D'Oderzo (province of Treviso) in the high Venetian-Friulian plain whose soil is rich in carbonates. The one of Nero d'Avola was in a mulch-clay soil in the plain in Susegana (province of Treviso).

In Marches, all three vineyards were close to each other in the clay soils of the Loreto hills (province of Ancona), one for Nero d'Avola and Refosco dal Peduncolo Rosso, and the other two for Verdicchio and Fiano.

The climatic conditions in 2009 and 2010 were different, as reported in Table 1: the minimum and maximum average temperatures were higher, the average rainfall lower, and the evapotranspiration values higher in 2009 than in 2010 in both the regions. The corresponding average values of Italy were higher for temperatures and for the evapotranspiration values; for rainfall, they were lower with the exception of the average rainfall of Marches in 2009. 
Table 1. Minimum and maximum average temperatures $\left({ }^{\circ} \mathrm{C}\right)$, rainfall $(\mathrm{mm})$, and evapotranspiration values (mm): average of 2009 and 2010 in Veneto, Marches, and Italy (data https:/ / www.politicheagricole.it).

\begin{tabular}{ccccccccc}
\hline & $\begin{array}{c}\text { Average Minimum } \\
\text { Temperature }\left({ }^{\circ} \mathbf{C}\right)\end{array}$ & \multicolumn{2}{c}{$\begin{array}{c}\text { Average Maximum } \\
\text { Temperature }\left({ }^{\circ} \mathbf{C}\right)\end{array}$} & $\begin{array}{c}\text { Average } \\
\text { Rainfall (mm) }\end{array}$ & $\begin{array}{c}\text { Average } \\
\text { Evapotranspiration }(\mathbf{m m})\end{array}$ \\
\hline VENETO & 2009 & 2010 & 2009 & 2010 & 2009 & 2010 & 2009 & 2010 \\
MARCHES & 7.3 & 6.7 & 16.6 & 15.4 & 904.3 & 1009.1 & 798.9 & 763.0 \\
ITALY & 9 & 8.3 & 17.9 & 16.6 & 839.0 & 1036.7 & 876.3 & 828.8 \\
\hline
\end{tabular}

The grapes were vinified in duplicate (50 $\mathrm{kg}$ for each repetition) in the experimental cellar of the CREA Research Centre for Viticulture and Enology (Asti), according to the official protocols established by Reg. EC 555/2008.

\subsection{White Wines Protocol}

The white grapes were crushed and pressed with a hydraulic press, then the juice, with added $\mathrm{SO}_{2}$ $(30 \mathrm{mg} / \mathrm{L})$ and pectolytic enzymes, was subjected to static defecation $\left(12-15^{\circ} \mathrm{C}\right)$ for about $18 \mathrm{~h}$. After raking, the musts were inoculated with a commercial selected yeast starter (Lievito TOP15 produced by ENARTIS). The fermentation was carried out at $18-20{ }^{\circ} \mathrm{C}$. The wines were added with $\mathrm{SO}_{2}(50 \mathrm{mg} / \mathrm{L})$, refrigerated for tartaric stabilization, clarified, filtered, and subsequently bottled.

\subsection{Red Wines Protocol}

The red grapes were crushed and destemmed, added with $\mathrm{SO}_{2}(30 \mathrm{mg} / \mathrm{L})$, and inoculated with selected yeasts (Uvaferm VRB). The maceration lasted 8-10 days with punching down twice daily. After racking, the wines were inoculated with bacteria Oenococcus oeni (Lalvin VP41) for the development of malolactic fermentation (MLF). The wines were then decanted, refrigerated for tartaric stabilization for 2 months, added with $\mathrm{SO}_{2}(30 \mathrm{mg} / \mathrm{L})$, and subsequently bottled in the February of the year after the harvest.

\subsection{Analyses}

All the samples of wines were submitted to chemical, physical, and isotopic analyses.

\subsubsection{Chemical-Physical Analyses}

The chemical-physical analyses, consisting of alcohol, dry extract, total acidity (g/L tartaric acid), volatile acidity ( $\mathrm{g} / \mathrm{L}$ acetic acid), and $\mathrm{pH}$ analysis, were performed according to standard methods (G.U. C.E. n. 272 3/10/1990).

Color intensity (E420 + E520) and hue (E420/E520) were measured in red wines. E420 was instead measured in white wines. The polyphenol indices were also determined according to the methodologies proposed by Di Stefano et al. [13].

\subsubsection{Isotopic Analyses}

Isotopic ratio (D/H) I (ppm) was measured by means of an NMR Bruker $300 \mathrm{MHz}$ equipped with an automatic sample changer (Bruker BioSpin, Karlsruhe, Germany); other isotopic ratios were measured by means of a Mass Spectrometer Micromass VG Optima ISOTEC with an elemental analyzer Carlo Erba (NA 1500 NC, Carlo Erba, Milan, Italy) equipped with an automatic Fisons sampler AS-800 (Carlo Erba, Milan, Italy) to determine $\delta^{13} \mathrm{C} \%$ vs. PDB and with a sampler ISOPREP 18 to analyze $\delta^{18} \mathrm{O} \%$ vs. SMOW.

In order to verify the geographical origin of wines, an isotopic database on authentic wines was used, issued since 1987 under the support of the "Ministero delle Politiche Agricole e Forestali-Ispettorato Centrale per la Repressione delle Frodi". 


\subsubsection{Sensory Analyses}

In the spring after vintage, the sensory analyses of the wines samples were performed by a panel of 12 expert judges ( 6 women and 6 men), all with extensive experience in wine sensory evaluation and belonging to the CREA Research Centre for Viticulture and Enology (Asti) technical and scientific staff.

The wines were identified with a 3-digit code, and the sensory sessions took place in a tasting room following ISO norms (8589-2007). Samples $(50 \mathrm{~mL}$ ) of the wines were evaluated in wine tasting glasses that follow ISO standard guidelines (3591-1977).

The sensory profiles were realized following a procedure derived from the ISO standards (11035-1994) and described in previous papers [14,15]. The descriptors to be included in a wine aroma wheel with unstructured scales were chosen from a predefined odor list [16] and integrated with visual and gustative descriptors. The choice of all sensory descriptors was performed during a preliminary tasting session. A frequency threshold for the attribute citations was established: the attributes of color, taste, and mouth-feel were chosen when their frequency of identification by the panel was greater than "(number of assessors $\times$ number of wines) $/ 2$ ". Regarding odor, its description is generally more complex: the 3rd-level descriptors were chosen when their frequency of identification was higher than "(number of assessors $\times$ number of wines) $/ 4$ ". All the selected attributes were confirmed and discussed by the panel with suitable standards (Table 2). A tasting sheet was created in order to measure the intensity of each chosen descriptor using an unstructured intensity scale presented on a wheel. Two replicates of samples of each wine were sensory analyzed.

Table 2. Reference materials for sensory analysis.

\begin{tabular}{|c|c|}
\hline & White Wines \\
\hline $\begin{array}{l}\text { Attributes } \\
\text { acacia blossoms } \\
\text { citrus } \\
\text { apple } \\
\text { hexotic fruits } \\
\text { peach-apricot } \\
\text { honey } \\
\text { caramel } \\
\text { fresh herbaceous } \\
\text { aromatic herbs }\end{array}$ & $\begin{array}{l}\text { Reference Standards (per } 300 \mathrm{~mL} \text { Neutral-Flavored White Base Wine) } \\
\text { essential oil }(0.05 \mathrm{~mL}) \\
\text { lemon fresh skin } \\
\text { fresh apple infused } \\
\text { hexotic fruit juice }(100 \mathrm{~mL}) \\
\text { peach juice }(50 \mathrm{~mL}) \text { and apricot juice }(50 \mathrm{~mL}) \\
\text { honey }(60 \mathrm{~mL}) \\
\text { caramel }(50 \mathrm{~mL}) \\
\text { 3-cis-esanol }(50 \mathrm{~g}) \\
\text { mixture of dried aromatic herbs }(10 \mathrm{~g})\end{array}$ \\
\hline aromatic herbs & Red Wines \\
\hline $\begin{array}{l}\text { Attributes } \\
\text { violet } \\
\text { berries } \\
\text { cherry } \\
\text { plums } \\
\text { marmalade } \\
\text { fresh herbaceous }\end{array}$ & $\begin{array}{l}\text { Reference Standards (per } 300 \mathrm{~mL} \text { Neutral-Flavored White Base Wine) } \\
\beta \text {-ionone }(0.3 \mu \mathrm{L}) \\
\text { iced mixed berries }(100 \mathrm{~g}) \\
\text { cherry artificial aroma }(0.05 \mathrm{~mL}) \\
15-20 \text { plums infused } \\
\text { plum jam }(60 \mathrm{~g}) \\
\text { 3-cis-esanol }(50 \mathrm{~g})\end{array}$ \\
\hline $\begin{array}{l}\text { Attributes } \\
\text { Acidity } \\
\text { Bitterness } \\
\text { Astringency }\end{array}$ & $\begin{array}{l}\text { Reference Standards (in Water) } \\
\text { citric acid }(0.5 \mathrm{~g} / \mathrm{L}) \\
\text { caffeine }(0.4 \mathrm{mg} / \mathrm{L}) \\
\text { alum }(1 \mathrm{~g} / \mathrm{L})\end{array}$ \\
\hline
\end{tabular}

\subsubsection{Statistical Analyses}

The results were subjected to ANOVA and the Tukey test (95\%). The quantitative results of the sensory descriptors (average value of the evaluations of individual tasters) common to the white wines (Fiano and Verdicchio) or to the red wines (Refosco dal Peduncolo Rosso and Nero d'Avola) and the corresponding chemical and isotopic data were subjected to the statistical analysis with Principal Component Analysis (PCA) (XLSTAT 7.5). 


\section{Results}

The isotopic parameters (Table 3), the chemical-physical results (Table 4), and the sensory analyses (Figures 1 and 2) constituted a dataset that allowed the study of the wine sample similarities through PCA (Figures 3-6).

Table 3. Isotopic parameters determined in white and red wine in the two vintages (2009-2010). The isotopic ratios are expressed in $\delta \%$ relative to V-PDB (Vienna-Pee Dee Belemnite) for $\delta^{13} \mathrm{C}$, V-SMOW (Vienna-Standard Mean Ocean Water) for $\delta^{18} \mathrm{O}$. Different letters in the same column indicate significant differences at ANOVA and Tukey test (95\%).

\begin{tabular}{|c|c|c|c|c|c|}
\hline White Wines & $(\mathrm{D} / \mathrm{H}) \mathrm{I}$ & (D/H)II & $R$ & $\delta^{13} \mathrm{C} \%$ vs. PDB & $\delta^{18} \mathrm{O} \%$ vs. SMOW \\
\hline Fiano Marches 2009 & $100.12 \mathrm{~cd}$ & $131.37 \mathrm{a}$ & $2.62 \mathrm{a}$ & $-28.78 \mathrm{a}$ & $4.53 \mathrm{~b}$ \\
\hline Verdicchio Marches 2009 & $101.13 \mathrm{~b}$ & $131.23 \mathrm{a}$ & $2.60 \mathrm{a}$ & $-26.96 c$ & $4.52 \mathrm{~b}$ \\
\hline Fiano Veneto 2009 & $100.83 \mathrm{bc}$ & $130.67 \mathrm{a}$ & $2.59 \mathrm{a}$ & $-28.07 b$ & $4.70 \mathrm{~b}$ \\
\hline Verdicchio Veneto 2009 & $102.30 \mathrm{a}$ & $130.33 \mathrm{a}$ & $2.55 \mathrm{~b}$ & $-26.08 \mathrm{~d}$ & $5.79 \mathrm{a}$ \\
\hline Fiano Marches 10 & $99.38 \mathrm{~d}$ & $130.55 \mathrm{a}$ & $2.63 \mathrm{a}$ & $-28.69 \mathrm{a}$ & $1.68 \mathrm{c}$ \\
\hline Fiano Veneto 10 & 100.29 bcd & 129.88 a & $2.59 \mathrm{a}$ & $-27.96 \mathrm{~b}$ & $1.40 \mathrm{c}$ \\
\hline Verdicchio Veneto 10 & 100.52 bc & $127.05 \mathrm{~b}$ & $2.53 \mathrm{~b}$ & $-27.12 \mathrm{c}$ & $1.58 \mathrm{c}$ \\
\hline $\operatorname{Pr}>\mathrm{F}$ & 0.000 & 0.001 & 0.000 & 0.000 & $<0.0001$ \\
\hline Significativity & yes & yes & yes & yes & yes \\
\hline Red Wines & $(\mathrm{D} / \mathrm{H}) \mathrm{I}$ & (D/H)II & $R$ & $\delta^{13} \mathrm{C} \%$ vs. PDB & $\delta^{18} \mathrm{O} \%$ vs. SMOW \\
\hline Refosco Marches 2009 & $102.38 \mathrm{a}$ & $130.32 \mathrm{a}$ & $2.55 \mathrm{a}$ & $-25.71 \mathrm{a}$ & $3.16 \mathrm{a}$ \\
\hline Nero d'Avola Marches 2009 & $103.00 \mathrm{a}$ & $129.60 \mathrm{a}$ & $2.52 \mathrm{ab}$ & $-26.23 \mathrm{ab}$ & $3.48 \mathrm{a}$ \\
\hline Refosco Veneto 2009 & $102.42 \mathrm{a}$ & $128.07 \mathrm{ab}$ & $2.50 \mathrm{ab}$ & $-28.90 \mathrm{~d}$ & $3.13 \mathrm{a}$ \\
\hline Nero d'Avola Veneto 2009 & $102.66 \mathrm{a}$ & 129.37 a & $2.52 \mathrm{ab}$ & $-27.84 c$ & $2.07 \mathrm{~b}$ \\
\hline Refosco Marches 2010 & $101.16 \mathrm{a}$ & 129.95 a & $2.57 \mathrm{a}$ & $-26.89 b$ & $2.07 \mathrm{~b}$ \\
\hline Nero d'Avola Marches 2010 & $101.37 \mathrm{a}$ & $129.10 \mathrm{a}$ & $2.55 \mathrm{a}$ & $-26.43 \mathrm{ab}$ & $2.08 \mathrm{~b}$ \\
\hline Refosco Veneto 2010 & $101.62 \mathrm{a}$ & $125.99 \mathrm{~b}$ & $2.45 \mathrm{~b}$ & $-28.46 \mathrm{~cd}$ & $0.14 \mathrm{~d}$ \\
\hline Nero d'Avola Veneto 2010 & $101.64 \mathrm{a}$ & $128.29 \mathrm{a}$ & $2.52 \mathrm{ab}$ & $-28.25 \mathrm{~cd}$ & $0.94 \mathrm{c}$ \\
\hline $\operatorname{Pr}>F$ & 0.037 & 0.001 & 0.014 & $<0.0001$ & $<0.0001$ \\
\hline Significativity & yes & yes & yes & yes & yes \\
\hline
\end{tabular}

Table 4. Chemical-physical parameters determined in white and red wines in the two vintages (2009-2010). Total acidity is expressed as tartaric acid, volatile acidity is expressed as acetic acid, TP index is total phenol index. Different letters in the same column indicate significant differences at ANOVA and Tukey test (95\%).

\begin{tabular}{|c|c|c|c|c|c|c|c|c|}
\hline White Wines & \multicolumn{2}{|c|}{ Alcohol $(\% V / V)$} & $\begin{array}{c}\text { Dry } \\
\text { Matter } \\
\text { (g/L) }\end{array}$ & pH & $\begin{array}{c}\text { Total } \\
\text { Acidity } \\
(\mathrm{g} / \mathrm{L})\end{array}$ & \multicolumn{2}{|c|}{ Volatile Acidity (g/L) } & $\begin{array}{l}\text { E420 (Color } \\
\text { Intensity) }\end{array}$ \\
\hline Fiano Marches 2009 & \multicolumn{2}{|c|}{$14.36 \mathrm{a}$} & $23.05 \mathrm{~b}$ & $3.11 \mathrm{c}$ & $8.40 \mathrm{ab}$ & \multicolumn{2}{|c|}{$0.41 \mathrm{a}$} & $0.14 \mathrm{bc}$ \\
\hline Verdicchio Marches 2009 & \multicolumn{2}{|c|}{$11.95 \mathrm{f}$} & $23.04 \mathrm{~b}$ & $3.05 \mathrm{~cd}$ & $8.25 \mathrm{ab}$ & \multicolumn{2}{|c|}{$0.28 \mathrm{~b}$} & $0.14 \mathrm{~cd}$ \\
\hline Fiano Veneto 2009 & \multicolumn{2}{|c|}{$13.62 \mathrm{c}$} & $21.9 \mathrm{bc}$ & $2.97 \mathrm{de}$ & $8.60 \mathrm{a}$ & \multicolumn{2}{|c|}{$0.36 \mathrm{a}$} & $0.17 \mathrm{a}$ \\
\hline Verdicchio Veneto 2009 & \multicolumn{2}{|c|}{$12.31 \mathrm{e}$} & $22.32 \mathrm{bc}$ & $3.55 \mathrm{a}$ & $6.20 \mathrm{~d}$ & \multicolumn{2}{|c|}{$0.22 \mathrm{bc}$} & $0.17 \mathrm{ab}$ \\
\hline Fiano Marches 10 & \multicolumn{2}{|c|}{$14.05 \mathrm{~b}$} & $21.00 \mathrm{c}$ & $3.07 \mathrm{c}$ & $6.85 c$ & \multicolumn{2}{|c|}{$0.23 \mathrm{bc}$} & 0.11 de \\
\hline Fiano Veneto 10 & \multicolumn{2}{|c|}{$14.28 \mathrm{a}$} & $22.55 \mathrm{bc}$ & $2.88 \mathrm{e}$ & $7.90 \mathrm{~b}$ & \multicolumn{2}{|c|}{$0.27 b$} & $0.11 \mathrm{e}$ \\
\hline Verdicchio Veneto 10 & \multicolumn{2}{|c|}{$13.01 \mathrm{~d}$} & $25.50 \mathrm{a}$ & $3.41 \mathrm{~b}$ & $6.45 \mathrm{~cd}$ & \multicolumn{2}{|c|}{$0.17 \mathrm{c}$} & $0.15 \mathrm{abc}$ \\
\hline $\operatorname{Pr}>\mathrm{F}$ & \multicolumn{2}{|c|}{$<0.0001$} & 0.001 & $<0.0001$ & $<0.0001$ & \multicolumn{2}{|c|}{$<0.0001$} & 0.000 \\
\hline Significativity & \multicolumn{2}{|c|}{ yes } & yes & yes & yes & \multicolumn{2}{|c|}{ yes } & yes \\
\hline Red Wines & $\begin{array}{l}\text { Alcohol } \\
(\% V / V)\end{array}$ & $\begin{array}{l}\text { Dry Matter } \\
\text { (g/L) }\end{array}$ & $\mathrm{pH}$ & $\begin{array}{c}\text { Total } \\
\text { Acidity } \\
(\mathrm{g} / \mathrm{L})\end{array}$ & $\begin{array}{c}\text { Volatile } \\
\text { Acidity } \\
\text { (g/L) }\end{array}$ & $\begin{array}{c}\text { T P } \\
\text { Index } \\
(\mathrm{mg} / \mathrm{L})\end{array}$ & $\begin{array}{l}\text { E420/E520 } \\
\text { (Color } \\
\text { Hue) }\end{array}$ & $\begin{array}{c}\text { E420 + E520 + } \\
\text { E620 (Color } \\
\text { Intensity) }\end{array}$ \\
\hline Refosco Marches 2009 & $12.68 \mathrm{a}$ & $23.50 \mathrm{bcd}$ & $3.75 \mathrm{ab}$ & $5.35 \mathrm{ab}$ & $0.40 \mathrm{~b}$ & $1227 \mathrm{bc}$ & $0.795 \mathrm{~b}$ & $0.585 \mathrm{~b}$ \\
\hline Nero Marches 2009 & $11.54 \mathrm{abc}$ & $22.95 \mathrm{~cd}$ & $3.15 \mathrm{~d}$ & $6.05 \mathrm{a}$ & $0.36 \mathrm{~b}$ & $1007 \mathrm{~d}$ & $0.610 \mathrm{~d}$ & $0.585 \mathrm{~b}$ \\
\hline Refosco Veneto 2009 & $10.54 \mathrm{~cd}$ & $21.30 \mathrm{e}$ & $3.48 \mathrm{bc}$ & $5.20 \mathrm{ab}$ & $0.61 \mathrm{a}$ & $924 \mathrm{~d}$ & $0.745 \mathrm{bc}$ & $0.340 \mathrm{~cd}$ \\
\hline Nero Veneto 2009 & $12.05 \mathrm{ab}$ & $22.40 \mathrm{de}$ & $3.29 \mathrm{~cd}$ & $6.10 \mathrm{a}$ & $0.41 \mathrm{~b}$ & $1091 \mathrm{~cd}$ & $0.665 \mathrm{bcd}$ & $0.455 \mathrm{c}$ \\
\hline Refosco Marches 2010 & $11.74 \mathrm{abc}$ & $25.55 \mathrm{a}$ & $3.80 \mathrm{a}$ & $6.10 \mathrm{a}$ & $0.33 \mathrm{~b}$ & $1370 \mathrm{ab}$ & $0.790 \mathrm{~b}$ & $0.620 \mathrm{~b}$ \\
\hline Nero Marches 2010 & $12.58 \mathrm{a}$ & $24.00 \mathrm{abc}$ & $3.66 \mathrm{ab}$ & $6.10 \mathrm{a}$ & $0.24 \mathrm{~b}$ & $1484 \mathrm{a}$ & $0.640 \mathrm{~cd}$ & $0.775 \mathrm{a}$ \\
\hline Refosco Veneto 2010 & $10.86 \mathrm{bcd}$ & $24.75 \mathrm{ab}$ & $3.89 \mathrm{a}$ & $4.95 \mathrm{~b}$ & $0.42 \mathrm{~b}$ & $1042 \mathrm{~d}$ & $0.930 \mathrm{a}$ & $0.425 c$ \\
\hline Nero Veneto 2010 & $9.83 \mathrm{~d}$ & $21.00 \mathrm{e}$ & $3.66 \mathrm{ab}$ & $5.30 \mathrm{ab}$ & $0.29 \mathrm{~b}$ & $1066 \mathrm{~cd}$ & $0.745 \mathrm{bc}$ & $0.260 \mathrm{~d}$ \\
\hline $\operatorname{Pr}>\mathrm{F}$ & 0.000 & $<0.0001$ & $<0.0001$ & 0.004 & 0.001 & $<0.0001$ & 0.000 & $<0.0001$ \\
\hline Significativity & yes & yes & yes & yes & yes & yes & yes & yes \\
\hline
\end{tabular}


The isotopic parameter $(\mathrm{D} / \mathrm{H}) \mathrm{I}(\mathrm{ppm})$ results (Table 3) showed significant differences among white wines of the same region (Fiano and Verdicchio 2009) or among the same wine of two vintages (Verdicchio Veneto). No differences were pointed out for this parameter among the red wines.

$(\mathrm{D} / \mathrm{H}) \mathrm{II}(\mathrm{ppm})$ showed similar value results in white and red wines in both regions.

A comparable situation was evidenced for the other isotopic parameters $\left(R, \delta^{13} \mathrm{C} \% 0\right.$ vs. PDB and $\delta^{18} \mathrm{O} \%$ vs. SMOW): significant differences did not discriminate wine varieties or region of origin.

Table 4 shows the results of the chemical-physical analysis and the color parameters of white and red wines in 2009 and 2010.

The values of the different parameters-alcohol, dry matter, $\mathrm{pH}$, total acidity, volatile acidity total polyphenols, and color measures-showed significant differences at ANOVA and Tukey test (95\%). The significant differences did not discriminate wine varieties or region of origin.

Sometimes the significant differences were among wines of the same region or among the same wine of two vintages.

The sensory profiles of wines were different not only for each variety but also for the vintages (Figures 1 and 2).

For visual aspect, Verdicchio had golden highlights, while Fiano had yellow highlights. Some olfactory descriptors were common for Fiano and Verdicchio, such as acacia blossom and aromatic herbs. Fiano was characterized by the presence of notes of honey and citrus in both vintages. The 2009 wines were all characterized by aromatic herbs and apple notes.

The average sensory profiles of red wines (Figure 2) were more similar than white wines. For visual aspect, the color was ruby red with violet highlights for all the samples, but in 2010 there were high differences in the intensity of these descriptors in the two zones, as confirmed from chemical parameters. Many olfactory descriptors were common, such as violet, cherry, and berries. Refosco was characterized by the presence of notes of fresh herbaceous while Nero d'Avola by plums and marmalade. There were no differences in the descriptors for the two vintages.

The sensory data and the chemical and isotopic parameters were used for statistical elaboration.

The results of the PCA for white wines are reported in Figure 3, which shows the score plot for the first two principal components, which together explain $67.41 \%$ of the total variance in the two vintages (2009 and 2010).

The PCA shows a good separation of the samples based on vintage and on grape varieties. PC1 is able to separate the samples coming from the two white varieties, Fiano and Verdicchio. In particular, the samples of Verdicchio (at negative values) are well separated from the Fiano ones (at positive values). PC2, on the other hand, separates the samples according to their production year. Samples obtained from 2009 vintage are at positive values, while those from 2010 vintage are at negative values. Loadings plots analysis for PC1 and PC2 (Figure 4) evidence the most important variables for the samples distribution observed in the score plot.

Fiano wines were characterized by a greater acidity (lower $\mathrm{pH}$ ), a yellowish color, and a better structure (body). On the other hand, Verdicchio wines had a greater softness, an intense acacia flowers fragrance, and a lower acidity. From an isotopic point of view, Verdicchio samples had a greater ${ }^{13} \mathrm{C} /{ }^{12} \mathrm{C}$ ratio. When considering the production year, 2009 samples had a greater $\mathrm{SO}_{2}$ content and an increased ${ }^{18} \mathrm{O} /{ }^{16} \mathrm{O}$ ratio, while 2010 ones had a greater bitterness. 


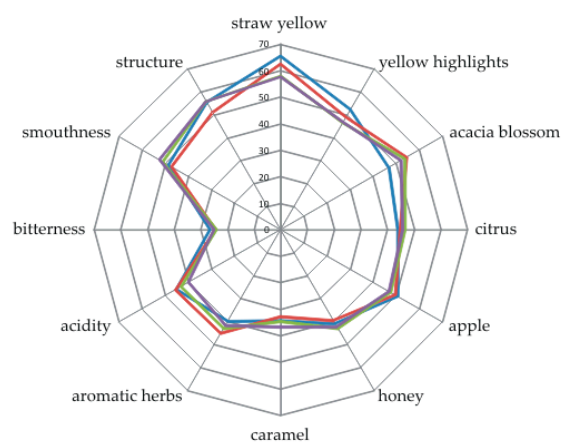

Fiano 2009

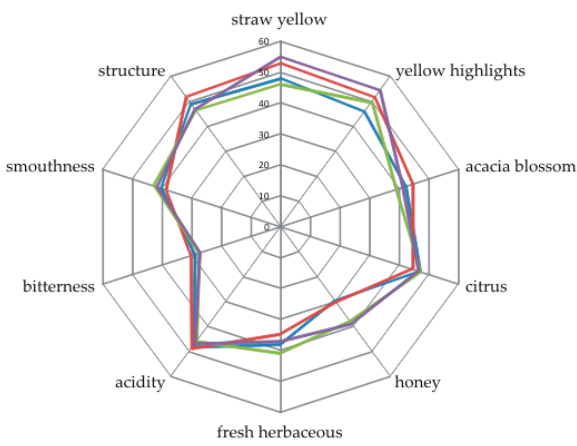

Fiano 2010

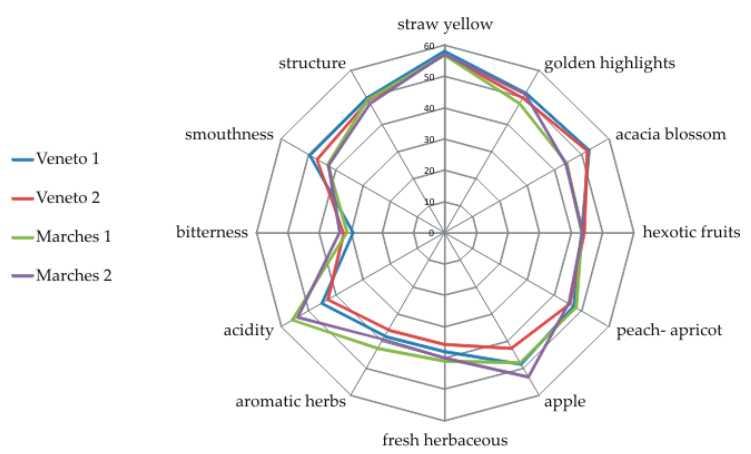

Verdicchio 2009
- Veneto 1

-Veneto 2

- Marches 1

- Marches 2

Figure 1. Sensory profiles of white wines.
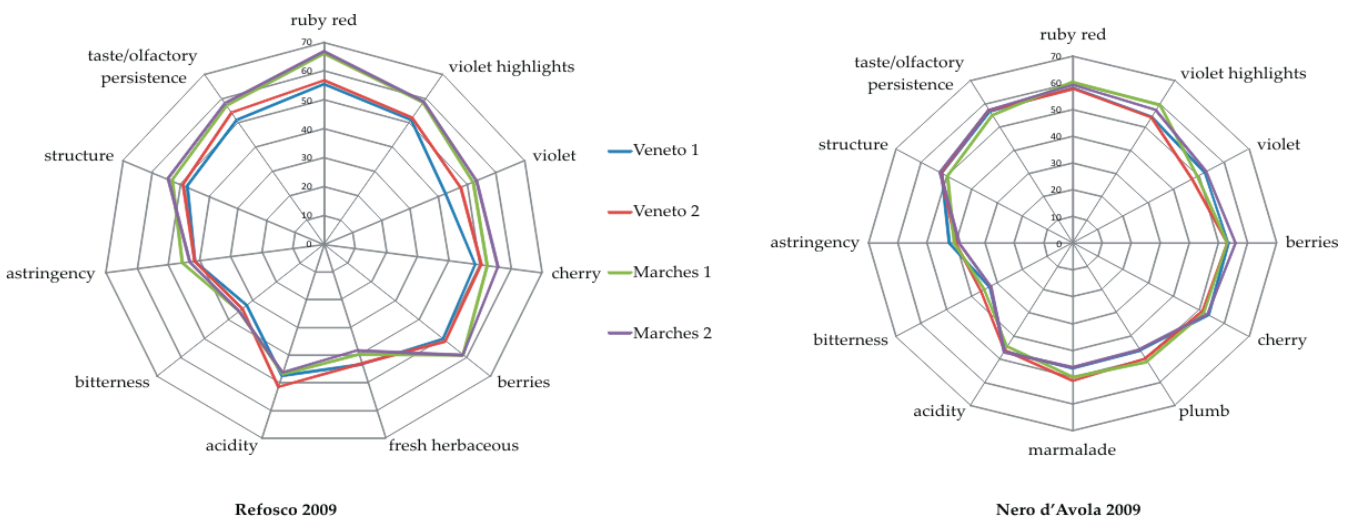

Nero d'Avola 2009
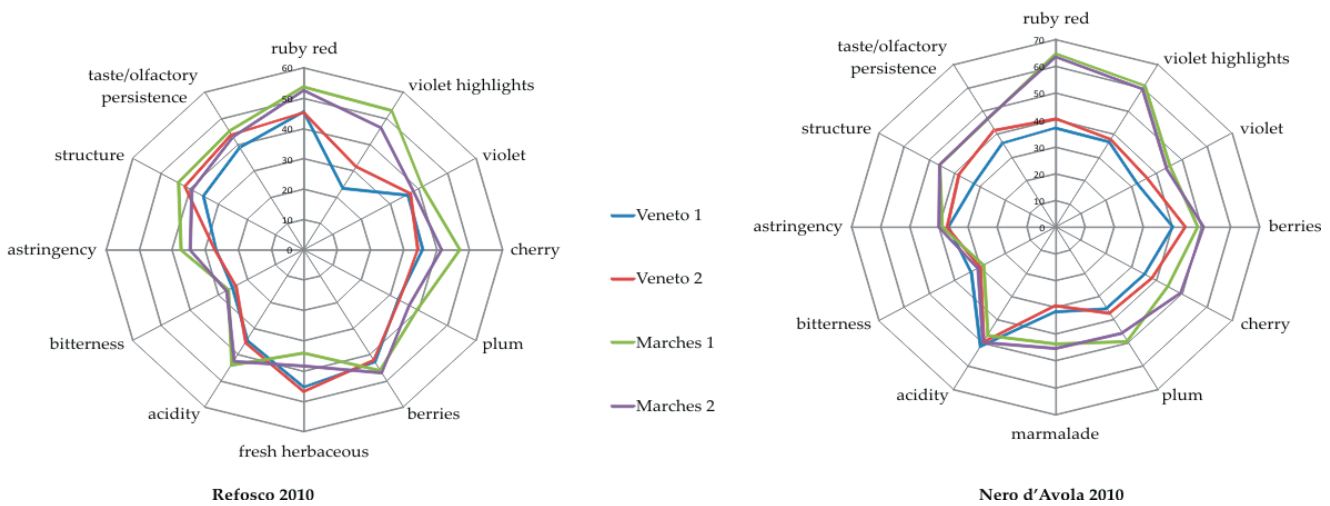

Refosco 2010

Nero d'Avola 2010

Figure 2. Sensory profiles of red wines. 


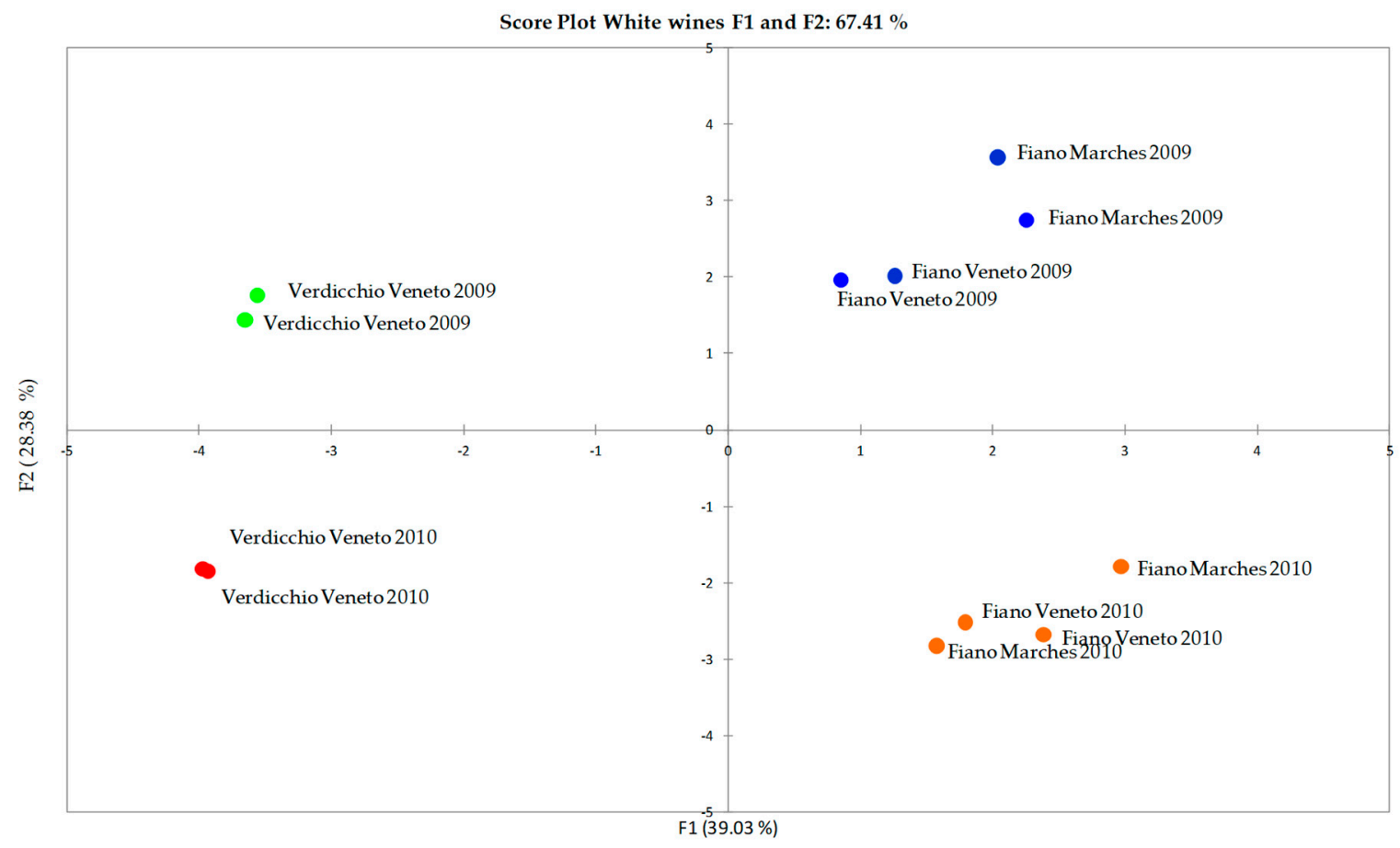

Figure 3. Score plot for white wines (Verdicchio and Fiano) in the two vintages (2009-2010).

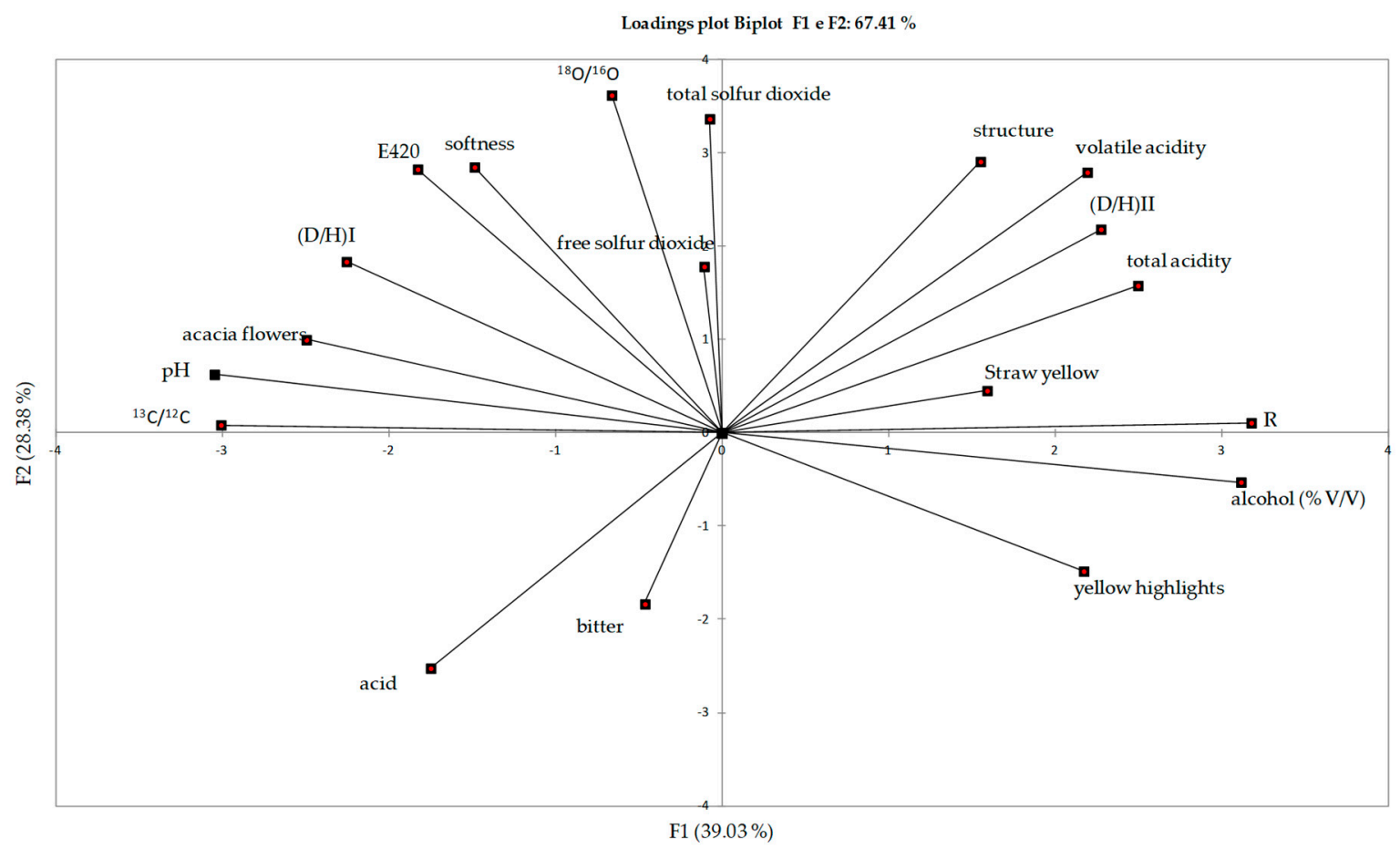

Figure 4. Loadings plot for white wines (Verdicchio and Fiano) in the two vintages (2009-2010).

Figure 5 shows the results of the PCA obtained considering all the data of the red wines. These samples are distributed along PC1 according to their production area while PC2 separates the two different vintages. The first two principal components together explain $60.50 \%$ of the total variance. 


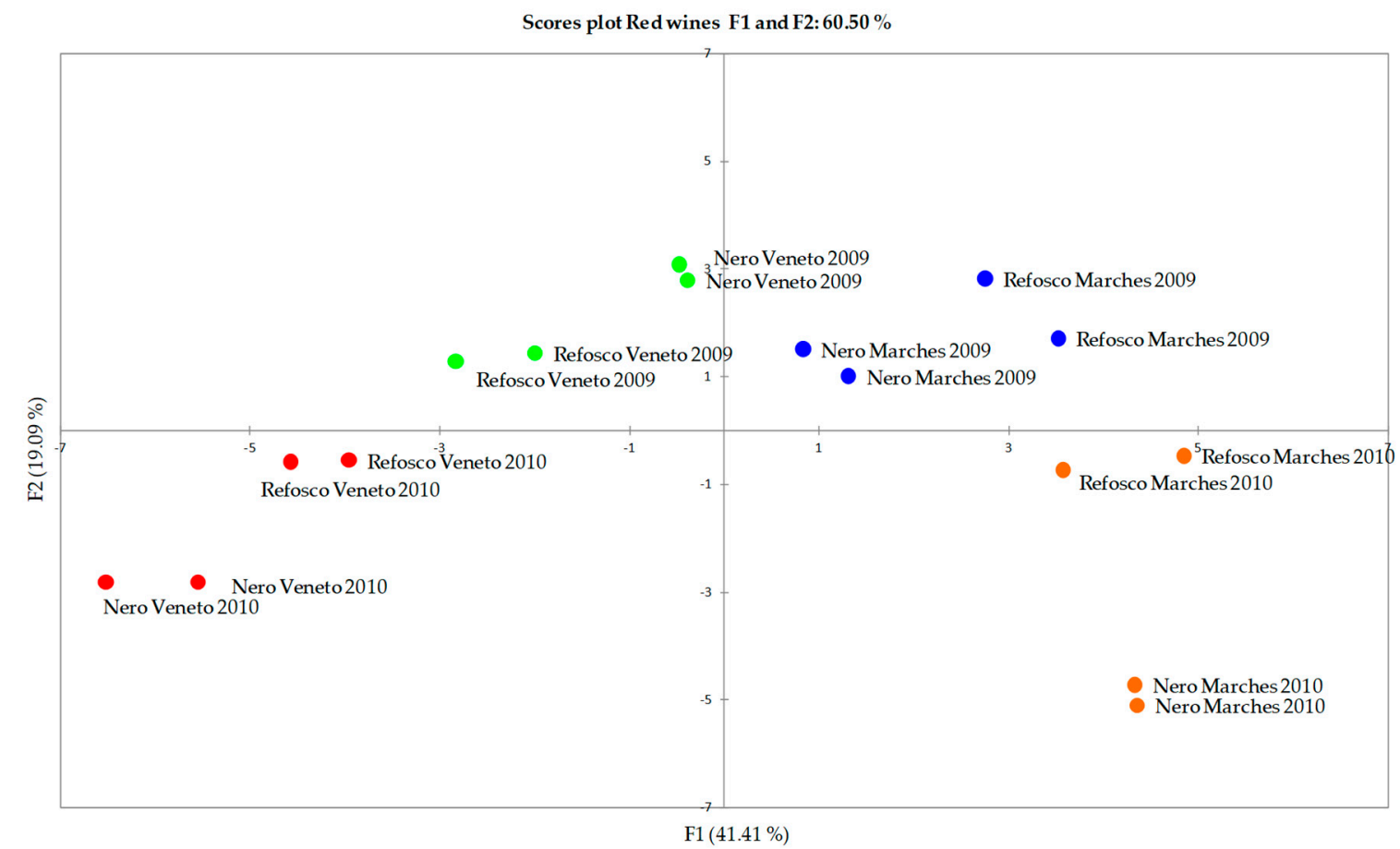

Figure 5. Score plot for red wines (Nero d'Avola and Refosco) in the two vintages (2009-2010).

Figure 6 shows the loadings plot that point out the parameters that most affect sample separation. Veneto samples showed a higher total acidity and color hue (E420/E520 ratio). Samples from 2009 vintage had a greater volatile acidity, bitterness, and lactic acid content. However, Marches samples were characterized by a major structure and persistence. These sensory parameters are correlated to the higher concentration of polyphenols, proanthocyanidins, and total flavonoids.

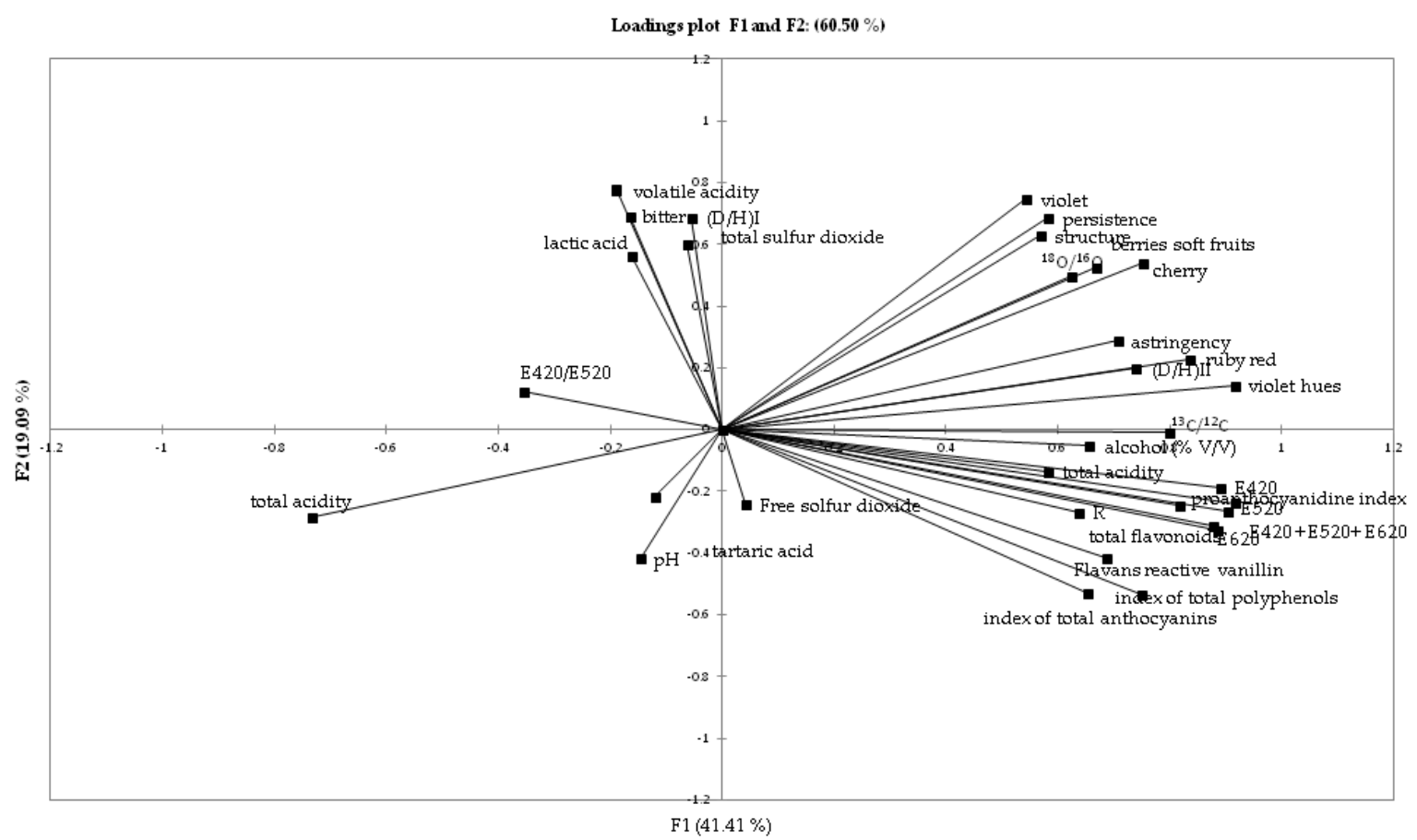

Figure 6. Loadings plot for white wines (Nero d'Avola and Refosco) in the two vintages (2009-2010). 


\section{Discussion}

Isotopic parameters are successfully used to determine the geographical origin, a key aspect of wine traceability, with the help of the EU isotopic yearly data bank reports.

However, these ratios are influenced by the climatic conditions of the vintage. For example, in 2003, when the whole climate of Italy was characterized by the presence of high temperatures and low rainfall, the differentiation of the wine origin areas was not so clear [17]. According to [10], in vintages with particular conditions, like low rainfall or very high temperature, it is very difficult to differentiate the provenance of wines only with isotopic ratios.

In this experience, the isotopic results detected in the wines produced from grapes coming from Veneto and Marches were very much alike. Veneto climate is subcontinental (hot summers and cold winters) but it is mitigated by the sea and protected from northern winds by the Alps. As for Marches, in the areas by the sea, the climate is subcontinental too. Despite different latitudes, Veneto and Marches climates were quite similar in the years examined (Table 1).

The wine chemical data and the sensory analysis alone or together cannot discriminate the geographical origin. The vintage has generally a more significant effect than the origin of wines (Denomination of Origin) on the chemical and sensory data, as shown by [18] on 18 Spanish local varieties. A previous study on Nero d'Avola wines [14] also pointed out the effect of the vintage on these parameters.

The PCA multivariate analysis of the chemical, sensory, and isotopic parameters showed to be very helpful to discriminate the geographical origin of wines. The red samples are distributed along PC 1 according to their production area while PC 2 separates the two different vintages. In the white wines, there is a good separation of the samples based on vintage and on grape varieties.

\section{Conclusions}

This study shows that the application of the multivariate PCA to the isotopic data, coupled with chemical analyses and wine sensory profiles, can be more effective in the assessment of the geographical origin of the wines tested. The multivariate analysis gives a global vision on the distribution of wines according to the vintage and the origin. The number of wines in the study was limited and it could be interesting to extend the analysis on a bigger dataset.

Author Contributions: Conceptualization: V.D.; Methodology: M.C.C., A.C.; Formal analysis: F.B., C.T., A.C.; Data curation: F.B., M.C.C., C.T., A.C., V.D.; Writing-Original Draft Preparation: F.B., V.D., M.C.C.; Writing—review \& editing: F.B., M.C.C.; Project administration: V.D.; Funding acquisition: V.D.

Funding: This research was funded by ENTECRA (now CREA, Council for Agricultural Research and Economics).

Acknowledgments: ENTECRA (now CREA) for the financial support and the sensory panel of the CREA Research Centre for Viticulture and Enology, in Asti (Italy) for the collaboration are gratefully acknowledged. The authors would like to thank Angelo Barrocu for collaborating on the analyses and Annamaria Di Franco for her help with the English text.

Conflicts of Interest: The authors declare no conflict of interest.

\section{References}

1. Camin, F.; Versini, G. Analisi innovative per marcare i prodotti lattiero-caseari di montagna. In Alpeggi e Produzioni Lattiero Casearie: Atti del Convegno; Regione Trentino-Alto Adige: Trento, Italy, 2001.

2. Durante, C.; Bertacchini, L.; Bontempo, L.; Camin, F.; Manzini, D.; Lambertini, P.; Marchetti, A.; Paolini, M. From soil to grape and wine: Variation of light and heavy elements isotope ratios. Food Chem. 2016, 210, 648-659. [CrossRef] [PubMed]

3. Santesteban, L.G.; Miranda, C.; Barbarin, I.; Royo, J.B. Application of the measurement of the natural abundance of stable isotopes in viticulture: A review. Aust. J. Grape Wine Res. 2015, 21, 157-167. [CrossRef]

4. Marchionni, S.; Braschi, E.; Tommasini, S.; Bollati, A.; Cifelli, F.; Mulinacci, N.; Mattei, M.; Conticelli, S. High-precision $87 \mathrm{Sr} / 86 \mathrm{Sr}$ analyses in wines and their use as a geological fingerprint for tracing geographic provenance. J. Agric. Food Chem. 2013, 61, 6822-6831. [CrossRef] [PubMed] 
5. Moreira, C.; de Pinho, M.; Curvelo-Garcia, A.S.; de Sousa, B.R.; Ricardo-da-Silva, J.M.; Catarino, S. Evaluating nanofiltration effect on wine $87 \mathrm{Sr} / 86 \mathrm{Sr}$ isotopic ratio and the robustness of this geographical fingerprint. S. Afr. J. Enol. Vitic. 2017, 38, 82-93. [CrossRef]

6. Martin, G.J.; Guillou, C.; Martin, M.L.; Cabanis, M.T.; Tep, Y.; Aerny, J. Natural factors of isotope fractionation and the characterization of wines. J. Agric. Food Chem. 1988, 36, 316-322. [CrossRef]

7. Versini, G.; Monetti, A. Come e possibile controllare analiticamente l'origine geografica di un vino. Enotecnico 1996, 32, 77-89.

8. Gremaud, G.; Quaile, S.; Piantini, U.; Pfammatter, E.; Corvi, C. Characterization of Swiss vineyards using isotopic data in combination with trace elements and classical parameters. Eur. Food Res. Technol. 2004, 219, 97-104. [CrossRef]

9. Geana, E.I.; Popescu, R.; Costinel, D.; Dinca, O.R.; Ionete, R.E.; Stefanescu, I.; Artem, V.; Bala, C. Classification of red wines using suitable markers coupled with multivariate statistic analysis. Food Chem. 2016, 192, 1015-1024. [CrossRef] [PubMed]

10. Aghemo, C.; Albertino, A.; Gobetto, R.; Spanna, F. Correlation between isotopic and meteorological parameters in Italian wines: A local-scale approach. J. Sci. Food Agric. 2011, 91, 2088-2094. [CrossRef] [PubMed]

11. Dutra, S.V.; Adami, L.; Marcon, A.R.; Carnieli, G.J.; Roani, C.A.; Spinelli, F.R.; Leonardelli, S.; Vanderlinde, R. Characterization of wines according the geographical origin by analysis of isotopes and minerals and the influence of harvest on the isotope values. Food Chem. 2013, 141, 2148-2153. [CrossRef] [PubMed]

12. Rochfort, S.; Ezernieks, V.; Bastian, S.E.; Downey, M.O. Sensory attributes of wine influenced by variety and berry shading discriminated by NMR metabolomics. Food Chem. 2010, 121, 1296-1304. [CrossRef]

13. Di Stefano, R.; Cravero, M.C.; Gentilini, N. Methods for the study of wine polyphenols. L'Enotecnico 1989, $25,83-89$.

14. Cravero, M.C.; Bonello, E.; Tsolakis, C.; Piano, E.; Borsa, D. Comparison between Nero d'Avola wines produced with grapes grown in Sicily and Tuscany. Ital. J. Food Sci. 2012, 24, 385-387.

15. Guaita, M.; Petrozziello, M.; Motta, S.; Bonello, F.; Cravero, M.C.; Marulli, C.; Bosso, A. Effect of the closure type on the evolution of the physical-chemical and sensory characteristics of a Montepulciano d'Abruzzo Rosé Wine. J. Food Sci. 2013, 78, C160-C169. [CrossRef] [PubMed]

16. Guinard, J.X.; Noble, A.C. Proposition d'une terminologie pour une description analytique de l'arôme des vins. Sci. Aliments 1986, 6, 657-662.

17. Bonello, F.; Cravero, M.C.; Tsolakis, C.; Ciambotti, A. Applicazione dei metodi isotopici e dell'analisi sensoriale negli studi sull'origine dei vini. In Proceedings of the VIII International Terroir Congress, Soave, Italy, 14-18 June 2010; Volume 2, pp. 69-74.

18. García-Muñoz, S.; Muñoz-Organero, G.; Fernández-Fernández, E.; Cabello, F. Sensory characterisation and factors influencing quality of wines made from 18 minor varieties (Vitis vinifera L.). Food Qual. Preference 2014, 32, 241-252.

(C) 2018 by the authors. Licensee MDPI, Basel, Switzerland. This article is an open access article distributed under the terms and conditions of the Creative Commons Attribution (CC BY) license (http:// creativecommons.org/licenses/by/4.0/). 